\title{
Sekema Multi Akad Mudharabah Musytarakah Dan Implikasinya
}

\author{
Muhammad Syakur
}

Institute Agama Islam Nahdatul Ulama (INISNU), Temanggung, Jawa Tengah, Indonesia, Email:emha.syakur@gmail.com

\begin{tabular}{l} 
Article Info \\
Article History: \\
Received : 01-01-2021 \\
Revised : 20-03-2021 \\
Accepted : 10-07-2021 \\
Published : 01-11-2021 \\
\hline
\end{tabular}

\section{Keywords:}

Islamic

Contract

Financial

\begin{abstract}
How is the implementation that can be used as the basis for multicontracts on financial transactions, what are the views of the scholars, schools that regulate the sale and purchase activities with contracts. The research method that the research uses is juridical observation.

Human needs that are increasing and growing have demanded humans to innovate in meeting their needs. This has a direct impact on the development of contract models. New contracts have finally emerged in the Islamic economic sectors. Among them is the multi-contract mudarabah musytarakah scheme on sharia insurance. The implication of the new contract model is one of the parties, in this case the insurance company has two sides of the contract or dual roles. The company as the manager of capital (mudārib) as well as the company participates as the owner of capital (sāhib al-māl). When a company manages the object of mudarabah mixed with the object of syirkah, it is possible that there will be mutual attraction of interests, namely the interests of the company as a participant (sāhibul mal) and one side of interest as the manager (mudārib). The two sides of the contract or dual roles have the basis of the opinion of the school (Hanābilah) as long as there is no suspicion (at-tuhmah) that violates the principles of independence and impartiality
\end{abstract}

Informasi Artikel

Histori Artikel:

Diterima : 01-01-2021

Direvisi : 20-03-2021

Disetujui : 10-07-2021

Diterbitkan : 01-11-2021

\section{Kata Kunci:}

Syariah

Akad

Keuangan

\begin{abstract}
Abstrak
Bagaimana Pelaksanaan yang Dapat dijadikan Landasan Multi Akad Terhadap Transaksi Keuangan, Bagaimana pandangan Para Ulama, Mazhab yang Mengatur Tentang Kegiatan Jual Beli Dengan Akad. Metode penelitian yang penelitian gunakan adalah yuridis observsi.

Hajat kebutuhan manusia yang semakin meningkat dan berkembang telah menuntut manusia untuk berinovasi dalam memenuhi kebutuhannya. Hal ini berakibat langsung bagi berkembangnya modelmodel akad. Akad-akad baru akhirnya muncul di sektor-sektor ekonomi syariah. Diantaranya adalah sekema multi akad mudarabah musytarakah pada asuransi syariah. Implikasi dari model akad baru tersebut salah satu pihak, dalam hal ini adalah perusahaan asuransi mempunyai dua sisi akad atau peran ganda. Perusahaan sebagai pengelola modal (mudārib) sekaligus perusahaan ikut sebagai pemilik modal (sāhib almāl). Ketika perusahaan mengelola objek mudarabah yang bercampur objek syirkah, maka dimungkinkan terjadi di dalamnya saling tarikmanarik kepentingan, yaitu kepentingan perusahaan sebagai peserta (sāhibul māl) dan satu sisi kepentingan sebagai pengelola (mudārib). Dua sisi akad atau peran ganda mempunyai dasar pendapat mazhab (Hanābilah) sepanjang tidak ada dugaan (at-tuhmah) menyalahi prinsip independensi dan imparsialitas
\end{abstract}




\section{PENDAHULUAN}

Bisnis Keuangan secara Islam di Indonesia hingga saat ini mengalami perkembangan yang signifikan. Hal ini ditandai dengan sejumlah sistem akad yang menerapkan secara syariah, banyaknya lembaga keuangan yang berorientasi kepada syariah serta semakin tingginya kesadaran masyarakat Indonesia dalam menerapkan kerja sama keuangan berdasarkan akad Mudharabah Musytarakah Dan Implikasinya, asuransi syariah, pasar modal syariah dan sebagainya. Khusus sistem keuangan syariah dikembangkan dalam rangka mengakomodir kebutuhan umat Islam di Indonesia yang ingin megembagnkan sistem keuagan di sektor-sektor ekonomi syariah. Diantaranya adalah sekema multi akad.

Sebagaimana diketahui bahwa Indonesia adalah merupakan sebuah negara dengan penduduk yang mayoritas beragama Islam dalam transaksi jual beli tidak lepas dilakukan akad secara syariah dan dalam istilah bahasa Inggris, penamaan multi akad diberikan istilah yang berbeda-beda. Ada yang menyebutnya hybird contract, ada pula yang menamakan combined contracts, combination of contract atau amalgamation of contracts. ${ }^{1}$

Dalam fikih klasik skema multi akad terjadi dalam akad bai' al-wafa', ialah akad penjaminan (tautsiqi) dalam rupa jual beli atas dasar masing-masing pihak mempunyai hak menarik kembali pada kedua imbalan (uang dan barang). Akad ini merupakan perpaduan antara jual beli dan gadai, namun hukum-hukum gadai (rahn) lebih dominan.

diharapkan bisa mengakomodir dan sekaligus melibatkan peran serta warga Muslim dimaksud secara langsung untuk ikut aktif menjadi pelaku utama transaksi keuangan menggunakan akad yang syariah, tentunya adalah masing - masing pihak. Sebagai upaya dalam merealisasikan hal tersebut maka sudah sewajarnya disediakan dan dikembangkan dalam transaksi dalam bentuk perusahaan keuangan juga dalam asuransi.

\footnotetext{
${ }^{1}$ Fatwa Dewan Syariah Nasional Majelis Ulama Indonesia No: 51/DSN-MUI/III/2006 tentang Mudharabah Musytarakah pada Asuransi Syariah.
} 


\section{ANALISA DAN PEMBAHASAN 1 \\ Pelaksanaan yang Dapat dijadikan Landasan Multi Akad Terhadap Transaksi Keuangan}

Multi akad juga terdapat dalam akad Rahn al-Musta'ar, ialah seseorang meminjam sesuatu kepada temannya tidak untuk dipakai, namun untuk digadaikan sebagai jaminan atas piutang. Perpaduan dua akad antara 'ariyah dan rahn tidak dibenarkan, karena sifat ke duanya bertentangan (mujibātun mutaḍātun). 'Ariyah termasuk akad tabarru' yang ghairu lāzim, orang yang meminjamkan boleh menarik pinjamannya kapanpun, sedangkan rahn adalah akad lāzimah, mengikat demi hak orang yang menghutangi (addā'in) sebagai penerima gadai (murtahin). ${ }^{2}$

Dalam fikih kontemporer pembahasan multi akad (aljam'u baina al-'uqud) terdapat dalam al-Mi'yar as-Syar'iy (Standar Syariah No. 25/2005: 655) AAOIFI (Accounting and Auditing Organisation for Islamic Financial). Definisi multi akad menurut AAOIFI adalah:

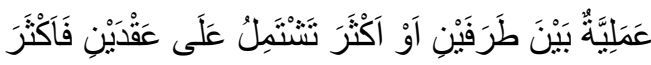

Aktifitas perjanjian antara dua orang/pihak atau lebih yang mengandung dua akad atau lebih.

Hukum multi akad menurut AAOIFI adalah boleh sepanjang berupa multi akad yang tidak mensyaratkan satu dengan lainnya, dan masing-masing akad adalah boleh dilaksanankan ketika sendiri-sendiri dan tidak ada dalil syariat yang khusus melarangnya. Jika ada dalil khusus yang melarangnya, maka sebagai pengecualian.

Syarat-syarat diperbolehkan skema multi akad oleh AAOIFI meliputi:

1. Tidak ada dalil nash yang melarangnya objek akad tertentu untuk digabungkan, seperti larangan menggabungkan al-bai' dan akad salaf (akad pesan).

2. Tidak ada rekayasa praktik riba, seperti kesepakatan bai' al-'inah dan rekayasa praktik riba fadli.

${ }^{2}$ Fatwa Dewan Syariah Nasional Majelis Ulama ndonesia No: 04/DSN-MUI/IV/2000 tentang

Haitami al-, Syihabuddin Ahmad ibn Muhammad ibn Ali ibn Hajar, Tuhfatul Muhtāj bisyarhi alMinhāj, t.tp.: t.p., t.t., 2 Vol. 
3. Tidak berpotensi riba, seperti mengumpulkan akad al-qardu (hutang) dan almu'āwadah (tukar menukar), atau menghutangi orang lain dengan syarat rumahnya boleh ditempati yang menghutangi, atau memberi hadiah kepada yang menghutangi, atau syarat pengembalian lebih baik kadar atau sifatnya.

4. Diantara akad-akad tidak saling bertentangan, berlawanan dalam hukumnya. Seperti multi akad hibah barang ( 'ain) dan jual beli, atau hibah dan ijarah (sewa), atau akad mudarabah dan menghutangkan modalnya ( $r a$ 'su al-māl), atau jual beli mata uang (sarf) dan ji'àlah, atau antara akad salam dan ji'älah dengan imbalan dari salah satu atau pula multi akad ijarah dan jual beli yang lebih dikenal dengan nama bai' alijari (konvensional).

Diantara model multi akad yang ada dalam sistem bisnis keuangan modern adalah al-Ijarah al-Muntahiyah bi at-Tamlik (IMBT), al-Murabahah lil Āmir bi as-Syirā' dan al-Musyarakah al-Mutanaqisah (MMQ).

Dalam konstruksi akad asuransi syariah, multi akad di dalamnya, tidak ada yang menyalahi persyaratan AAOIFI. Akad-akad yang terhimpun di dalamnya berupa akad muḍharabah, musyarakah dan hibah, masing-masing merupakan akad yang diperbolehkan ketika berdiri sendiri. Tidak ditemukan unsur rekayasa praktik riba, lebih-lebih asuransi syariah semangatnya adalah bebas riba. Multi akad dalam asuransi syariah tidak berpotensi riba dan dalam akad yang satu dengan lainnya tidak saling bertentangan, berlawanan dalam hukumnya. Namun, dari sisi akad yang ditimbulkannya, penulis temukan unsur peran ganda (ittihād al qābiẹ wa al muqbị̣).

Dalam Fatwa DSN-MUI No.51/DSN-MUI/III/2006 tentang Akad Mudharabah Musytarakah pada Asuransi dijelaskan bahwa akad Mudhrabah Musytarakah adalah perpaduan dari akad Mudhrabah dan Musyarakah. Perusahaan asuransi sebagai mudharib menyertakan modal atau dananya dalam investasi bersama dana peserta. Selanjutnya modal atau dana perusahaan asuransi dan dana peserta diinvestasikan secara bersama-sama dalam portofolio. Perusahaan sebagai mudharib mengelola investasi dana tersebut.

Konstruksi dalam akad ini termasuk kategori multi akad, yaitu akad muḍhrabah dan musyarakah, keduanya dipadukan dalam satu akad. Hal yang menjadi permasalahan bukan syarat-syarat multi akadnya, sebab penulis menilai sudah memenuhi persyaratan 
standar AAOIFI seperti telah penulis bahas sebelumnya, melainkan pada substansi salah satu pihak (al-'âqid), khususnya perusahaan asuransi, yang mempunyai peran ganda yaitu sebagai mudharib (pengelola) dan sekaligus sahibul mal (pemilik modal). Dalam kaidah fikih, dilarang dalam satu pihak terjadi kesatuan penerima (al-qābid) dan penyerah (al-muqbid). ${ }^{3}$ Dicontohkan, seorang yang menggadaikan (rahin) mewakilkan kepada penerima gadai (murtahin) untuk menjualkan barang gadainya sebagai tebusan hutang yang ditanggung rahin, maka perwakilan tersebut tidak sah, dkarenakan rahin berperan ganda, sebagai yang menyerahkan uang hasil penjualan barang gadai kepada dirinya sendiri sebagai yang mempunyai hak (piutang). Larangan peran ganda ini dikarenakan secara manusiawi tidak mungkin dua karakter penerima bersatu dengan karakter yang menyerahkan, sebab karakter "penerima" (al-qābid) tentu akan berusaha secepat mungkin agar hutangnya ditebus, sedangkan karakter "yang menyerahkan" (almuqbid) seharusnya dia menjualkan barang gadai tersebut dengan kehati-hatian dan tidak tergesa-gesa. Untuk mengantisipasi terjadinya tarik-menarik kepentingan yang mengakibatkan prasangka yang tidak-tidak dari para peserta (at-tuhmah) dalam akad ini, maka peran ganda dalam suatu perjanjian dilarang. ${ }^{4}$

Akad mudhrabah musytarakah, menurut analisa penulis, salah satu pihak, dalam hal ini adalah perusahaan asuransi mempunyai peran ganda. Di mana perusahaan sebagai pengelola modal (mudharib) sekaligus perusahaan ikut sebagai pemilik modal (sahibul mal). Ketika perusahaan mengelola objek mudarabah yang bercampur objek syirkah, maka dimungkinkan terjadi di dalamnya saling tarik-manarik kepentingan, yaitu kepentingan bagi perusahaan dan satu sisi kepentingan sebagai pelaksana amanat dari peserta (sahibul mal).

Masalah ini penulis padankan dengan Fatwa DSN-MUI No: 04/DSN-MUI/IV/2000 tentang Murabahah, dalam Ketentuan Umum Murabahah pada Bank Syariah poin 9 disebutkan:

\footnotetext{
${ }^{3}$ Kasāni al-, 'Ala’udīin Abi Bakr bin Mas’ud, Badai' as-Sanai', Beirut: Dar al-Fikr: 1417 H/1996 M., 5 Vol.

${ }^{4}$ Ibid.
} 
Jika bank hendak mewakilkan kepada nasabah untuk membeli barang dari pihak ketiga, akad jual beli murabahah harus dilakukan setelah barang, secara prinsip, menjadi milik bank.

Artinya, barang sudah harus diserah terimakan lebih dahulu dari pihak wakil ke pihak bank. Keharusan barang secara prinsip menjadi milik bank, penulis pahami selain mengantisipasi terjadinya jual beli barang yang belum ada dalam kepemilikan bank (bai' $a l-f u d \underline{u} l i)$, juga sebagai antisipasi terjadinya peran ganda dari pihak nasabah. Singkatnya menghindari terjadinya nasabah menjadi penerima sekaligus penyerah objek murabahah.

\section{ANALISA DAN PEMBAHASAN 2}

\section{Pandangan Para Ulama, Mazhab yang Mengatur Tentang Kegiatan Jual Beli Dengan Akad}

Dalam jual beli terdapat unsur-unsur akad yang salah satunya adalah para pihak (al-'Áqidain). Para pihak tersebut mempunyai kedudukan sendiri-sendiri, salah satu pihak sebagai yang menawarkan (al-Müjib), pihak lain sebagai penerima (al-Qābil) atau salah satunya sebagai yang menyerahkan (al-Muqbị̣), dan lainnya sebagai yang menerima (al-Qabiạ). Jika terjadi dalam perjanjian dua kedudukan tersebut dilakukan oleh satu subjek akad, yaitu sebagai yang menawarkan sekaligus yang menerima, atau sebagai yang menyerahkan sekaligus sebagai penerima, maka terdapat perbedaan pandangan para ulama' mazhab.

Mahir Zīb Abu Syawisy dalam masalah ini telah membagi perbedaan pandangan antar mazhab menjadi dua kelompok, yaitu pandangan al-Mudayyiqīn (sempit/melarang) dan al-Muwassi'īn (longgar/yang membolehkan). ${ }^{5}$

Kelompok Pertama (al-Mudayyiq'īn) Pandangan yang melarang adalah dari fukaha mazhab Hanafi, Syafi'i, dan satu dari dua riwayat pendapatnya Imam Malik. Mereka berpendapat bahwa hukum asal perikatan yang dilakukan oleh satu subjek akad yang menduduki dua pihak sekaligus adalah tidak sah dan dilarang kecuali dalam hal-hal tertentu yang sangat terbatas.

Māhir Zīb Abu Syāwīsy, Tawallī Țarafay ‘aqd al Bai’ fi al-Fiqh al-Islami, Majallah 'Ilmiyyah Muhakkamah: Journal Vol. 30, 2012. 
Mazhab Hanafiyah berpedapat tidak sah satu subjek akad menduduki dua pihak dalam akad, kecuali dalam masalah berikut:

- Menjualnya seorang pengampu anak yatim (al-Wași $)$ atas barang miliknya sendiri untuk anak yatim tersebut.

- Menjualnya seorang $Q \bar{a} d \underline{\text { a }}$ atas barang milik seorang yatim untuk anak yatim lainnya yang masing-masing dalam perwaliannya.

- Menjualnya seorang bapak atas barang miliknya untuk anak kecilnya sendiri, atau membeli barang milik anak untuk dirinya sendiri, atau menjual barang milik salah satu anaknya untuk anaknya yang lain yang sama-sama dalam perwaliannya.

Al-Kasāni menyatakan:

"Tidak sepantasnya dalam jual beli, satu orang menduduki sekaligus dua sisi, sebagai penjual dan pembeli, kecuali dalam masalah seorang ayah menjual miliknya untuk anak yang dalam perwaliannya dengan harga standar atau harga yang umumnya orang merugi (harga miring), atau sebaliknya membeli untuk dirinya dari barang anak yang dalam perwaliannya dengan harga umum atau bahkan sedikit mahal". 6

Di bagian lain al-Kasāni mengatakan:

"Seorang wakil dalam membelikan sesuatu tidak boleh dari barang miliknya sendiri, dikarenakan akan terjadi kerancuan yang mustahil terjadi, dimana satu orang pada saat yang sama menjadi pihak yang menyerahkan dan sekaligus menjadi penerima atau pihak yang membeli dan sekaligus sebagai penjual". ${ }^{7}$

Ibnu Hammām menegaskan:

"Perlu diketahui, bahwa satu orang tidak mungkin menduduki sebagai kedua pihak dalam jual beli, terkhusus hanya bagi seorang ayah dari anak kecil yang membeli dari anaknya untuk dirinya sendiri, atau sebaliknya".

Mazhab Syafi'iyyah berpendapat bahwa hukum asal tidak sah dan melarang satu orang berperan sebagai dua pihak dalam jual beli. Oleh karenanya tidak sah satu orang sebagai

Māhir Zīb Abu Syāwīsy, Tawallī Ṭarafay ‘aqd al Bai’ fi al-Fiqh al-Islami, Majallah 'Ilmiyyah Muhakkamah: Journal Vol. 30, 2012.

Qurțubi al-, Muhammad ibn Ahmad ibn Muhammad ibn Ahmad Ibn Rusyd, Bidayat alMujtahid wa Nihayat al-Muqtasid, cet. ke-4, Beirut: Dar al-Kutub al-Ilmiyyah: 2007, 5 Vol. 
wakil dari pihak pembeli dan sekaligus wakil dari pihak penjual. Dikecualikan masalahmasalah tertentu yang dapat dihitung jari. Imam Jalaluddin Abdurrahman as-Suyuthi dalam Asbah wa an-Nadair menyebutkannya sebagai berikut: ${ }^{9}$

- Seorang ayah atau kakek yang menjualkan barang milik anak kecilnya kepada dirinya sendiri atau sebaliknya, membelikan anak kecilnya barang dari miliknya sendiri.

- Perwakilan seseorang untuk menjualkan barang miliknya kepada wakil untuk dibeli sendiri oleh wakil dengan harga yang telah ditentukan dan tidak boleh lebih dari harga tersebut. Namun dalam kitab al-Matlab hal tersebut hukumnya boleh dikarenakan tidak ada syak-wasangka (at-Tuhmah).

Pendapat-pendapat ulama' Syafi'iyyah diantaranya:

1. Ibnu Hajar al-Haitami: Tidak boleh seorang wakil menjual kepada dirinya sendiri walau ada izin dari yang mewakilkan dan telah ditentukan harganya tidak boleh lebih dari harga tersebut. Pedapat ini berseberangan dengan pendapatnya Ibnu ar-Rif'ah. Illat larangan tunggalnya dua pihak dalam satu orang bukan karena adanya kesangsian (attuhmah), namun lebih pada tidak dimungkinkannya terjadi ijab dan kabul dari satu orang, terkecuali seorang ayah, dikarenakan ada sesuatu hal ('āridy). ${ }^{10}$

2. Imam as-Syarbini: Jika seorang penjual mewakilkan kepada orang lain untuk menjualkan barangnya, dan di pihak yang lain pembelinya menunjuk orang itu juga untuk mewakilinya dalam menerima barang, maka perwakilan yang demikian itu tidak sah, dikarenakan terjadi tunggalnya penerima dan yang menyerahkan dalam satu orang. ${ }^{11}$

Mazhab Maliki dalam satu riwayat lain melarang dan menghukumi tidak sahnya akad jual beli yang dilakukan oleh satu orang yang berperan sebagai dua pihak. Namun riwayat ini tidak masyhur sebagai pendapat mazhabnya.

Ibnu Rusyd menyinggung dua riwayat Imam Malik tersebut saat ditanyakan kepadanya: "Ketika seseorang diangkat sebagai wakil untuk menjualkan sesuatu, apaka

Suyuthi as-, Abdurrahman ibn Abi Bakr, al-Asybah wa al-Nadzair, Semarang: Toha Putra, t.t. Syarbini asy-, Muhammad bin Muhammad, Mughni al-Muhtāj Ilā Ma'rifati Ma'āni Alfazi alMinhāj, Mesir: Musthafa al-Babī al-Halabī, t.t., 2 Vol. 
boleh ia sendiri yang menjadi pembelinya? Ia mejawab: Pendapat Imam Malik adalah boleh, namun pendapat Imam Malik dari riwayat yang lain, tidak boleh". ${ }^{2}$

Kelompok Kedua (al-Muwassi'īn) Kelompok kedua ini (yang membolehkan) didukung oleh dua mazhab: pertama, pendapat yang membolehkan dari mazhab Maliki dari jalur riwayat lain, dan ini pendapat yang masyhur sebagai pendapat mazhabnya. Menurut pendapat ini, hukum asal satu orang berperan sebagai dua pihak dalam jual beli adalah sah. Dalam saat yang sama seseorang bisa menjadi yang menawarkan (al-Müjib) dan sekaligus yang menerima (al-Qābil), atau yang menerima barang (al-Qābiọ) dan sekaligus yang menyerahkan barang (al-Muqbị̣). Satu orang berfungsi sebagai dua pihak ini bisa terjadi sekalipun hanya menjadi wakil atau pengampu (al-wāṣi $)$. Namun demikian, pendapat ini mensyaratkan harus tidak adanya unsur mementingkan atau mencari keuntungan diri sendiri.

Pendapat ualama-ulama mazhab ini:

1. Ibnu Syasy: Seorang ayah boleh memfungsikan dirinya sebagai dua pihak dalam urusan jual-beli anak kecilnya. Demikian juga diperbolehkan bagi seorang wakil yang diserahi menjualkan sesuatu untuk sekaligus ia sendiri sebagai pembelinya.

2. Ibnu Juzayyi: Diperbolehkan bagi seorang wakil (menjualkan barang) dan pengampu untuk membeli barang milik orang yang mewakilkan (muwakkil) atau milik anak yatim yang dalam pengampuannya dengan syarat tidak ada unsur mementingkan atau menguntungkan diri pribadi.

kedua, mazhab Hanabilah. Dalam masalah ini mazhab Hanbali memiliki keluasan dibanding mazhab-mazhab yang lain. Pendapat mazhabnya membolehkan satu orang berperan sebagai dua pihak dalam akad jual beli. Hal ini didasarkan pada asas kebebasan berakad yang termasuk di dalamnya kebebasan menentukan syaratsyaratnya, dikarenakan asal hukum perjanjian adalah mubah sepanjang tidak ada dalil yang mengharamkannya. Demikian juga dalam masalah menguasainya satu orang atas fungsi dua pihak, hukum asalnya adalah boleh, karena tidak ada dalil syarak yang melarangnya. Namun mazhab ini mensyaratkan satu syarat, yaitu tidak adanya syakwasangka (at-Tuhmah). 
Dari uraian di atas praktis hanya satu mazhab yang membolehkan satu orang menduduki peran dua pihak dalam jual beli, yaitu mazhab Hanabilah, itupun ada satu syarat yang harus dipenuhi, yaitu tidak adanya potensi atau dugaan (at-Tuhmah) memihak kepentingannya sendiri.

Multi akad pada produk mudharabah musytarakah yang berimplikasi terjadinya peran ganda dari satu orang yang menduduki fungsi dua pihak sekaligus tidak mempengaruhi sahnya multi akad dan mudarabah musytarakah sepanjang tidak ada potensi memihak sebagaimana pandangan mazhab Hanābilah.

Peran ganda dalam perusahaan asuransi syari'ah meskipun mempunyai dasar pendapat mazhab (Hanābilah), namun masih perlu dikaji lagi apakah dalam multi akad tersebut mempunyai potensi atau dugaan (at-tuhmah) menyalahi prinsip independensi dan imparsialitas atau tidak?

\section{KESIMPULAN}

1. Peluang Multi Akad terhadap transaksi keuangan menurut AAOIFI adalah boleh sepanjang berupa multi akad yang tidak mensyaratkan satu dengan lainnya, dan masingmasing akad adalah boleh dilaksanankan ketika sendiri-sendiri dan tidak ada dalil syariat yang khusus melarangnya.

2. Pemikiran para Ulama ,Mazhab tentang jual beli memiliki pendapat yang berbeda dalam menilai apakah transaksi menggunakan Akad dalam Jual beli mengandung unsur-unsur yang dilarang secara syariah.

\section{DAFTAR PUSTAKA}

Fatwa Dewan Syariah Nasional Majelis Ulama Indonesia No. 21DSN-MUI/X/2001 tentang Pedoman Umum Asuransi Syarah.

Fatwa Dewan Syariah Nasional Majelis Ulama Indonesia No: 51/DSN-MUI/III/2006 tentang Mudharabah Musytarakah pada Asuransi Syariah.

Fatwa Dewan Syariah Nasional Majelis Ulama Indonesia No: 53/DSN-MUI/III/2006 tentang Tabarru' pada Asuransi Syariah. 
Fatwa Dewan Syariah Nasional Majelis Ulama ndonesia No: 04/DSN-MUI/IV/2000 tentang Murabahah

Haitami al-, Syihabuddin Ahmad ibn Muhammad ibn Ali ibn Hajar, Tuhfatul Muhtāj bisyarhi al-Minhāj, t.tp.: t.p., t.t., 2 Vol.

Kasāni al-, 'Ala’udīin Abi Bakr bin Mas'ud, Badai' as-Sanai', Beirut: Dar al-Fikr: 1417 H/1996 M., 5 Vol.

Māhir Zīb Abu Syāwīsy, Tawallī Ṭarafay 'aqd al Bai’ fi al-Fiqh al-Islami, Majallah 'Ilmiyyah Muhakkamah: Journal Vol. 30, 2012.

Qurțubi al-, Muhammad ibn Ahmad ibn Muhammad ibn Ahmad Ibn Rusyd, Bidayat alMujtahid wa Nihayat al-Muqtasid, cet. ke-4, Beirut: Dar al-Kutub alIlmiyyah: 2007, 5 Vol.

Suyuthi as-, Abdurrahman ibn Abi Bakr, al-Asybah wa al-Nadzair, Semarang: Toha Putra, t.t.

Syarbini asy-, Muhammad bin Muhammad, Mughni al-Muhtāj Ilā Ma'rifati Ma'āni Alfazi al-Minhāj, Mesir: Musthafa al-Babī al-Halabī, t.t., 2 Vol.

Zarqa' az-, Musthafa Ahmad, Al-Fiqh al-Islāmi fì Tsaubihi al-Jadīd al-Madkhal alFiqh al- 'Ām, Beirūt: Dār al- Fikr, 1968, 2 Vol. , Nidzām at-Ta'mīn Haqīqatuhu wa ar-Ra'yu as-Syar'iy fìh, Beirūt: Muassasah ar-Risālah, 1984 M.-1404 H. 